\title{
PHOSPHORUS AVAILABILITY IN SOIL INCUBATED WITH BIOCHAR: ADSORPTION STUDY ${ }^{1}$
}

\author{
JOSELY DANTAS FERNANDES ${ }^{2}$, LÚCIA HELENA GARÓFALO CHAVES ${ }^{2 *}$, EDILMA RODRIGUES BENTO \\ DANTAS $^{2}$, GILVANISE ALVES TITO $^{2}$, HUGO ORLANDO CARVALLO GUERRA ${ }^{2}$
}

\begin{abstract}
Considering the losses of phosphorus $(\mathrm{P})$ in the soil by the adsorption process and that the use of biochar seems promising from the agricultural point of view, the aim of this research was to evaluate $\mathrm{P}$ adsorption by the Ultisol incubated with different biochar doses through kinetic and isothermal study. The experiment was carried out with poultry litter biochar pyrolyzed at $350{ }^{\circ} \mathrm{C}$. Ultisol was incubated with increasing biochar doses, from 0.0 to $61.95 \mathrm{t} \mathrm{ha}^{-1}$. After 60 days, the phosphorus adsorption rate, kinetics and adsorption isotherms were evaluated. The results showed that the soil had the highest capacity to adsorb phosphorus (1.105 $\mathrm{mg} \mathrm{g}^{-1}$ ). Biochar was not a good $\mathrm{P}$ adsorbent; regardless of the applied doses, it released $\mathrm{P}$ to the equilibration solution. Langmuir model was better at describing the adsorption of $\mathrm{P}$. The pseudo-second order model fitted well to the adsorption kinetics of $\mathrm{P}$, showing that the adsorption is chemically controlled. These results suggest that biochar can increase the availability of $\mathrm{P}$, limiting adsorption; therefore, it could be used as a fertilizer and/or soil conditioner.
\end{abstract}

Keywords: Adsorption isotherms. Poultry litter. Kinetics. Physicochemical properties.

\section{DISPONIBILIDADE DE FÓSFORO NO SOLO INCUBADO COM BIOCARVÃO: ESTUDO DE ADSORÇÃO}

RESUMO - Considerando as perdas de fósforo (P) no solo pelo processo de adsorção e que o uso do biocarvão parece promissor do ponto de vista agrícola, objetivou-se com este estudo avaliar o processo de adsorção de $\mathrm{P}$ pelo solo Argissolo incubado com diferentes doses de biocarvão através de estudo cinético e isotérmico. O experimento foi realizado com biocarvão de cama de aviário pirolisado a $350{ }^{\circ} \mathrm{C}$. O Argissolo foi incubado com doses crescentes de biocarvão, de 0,0 a $61,95 \mathrm{t} \mathrm{ha}^{-1}$. Após 60 dias, foram avaliadas a taxa de adsorção de fósforo, e cinética e isotermas de adsorção. Os resultados mostraram que o solo apresentou a maior capacidade de adsorção de fósforo (1,105 $\left.\mathrm{mg} \mathrm{g}^{-1}\right)$. O biocarvão não foi um bom adsorvente de $\mathrm{P}$; independente das doses aplicadas, liberou P para a solução de equilíbrio. O modelo de Langmuir foi o melhor para descrever a adsorção de P. A cinética de adsorção de $\mathrm{P}$ se ajustou bem ao modelo de pseudo-segunda ordem, mostrando que a adsorção é controlada quimicamente. Esses resultados sugerem que o biocarvão pode aumentar a disponibilidade de $\mathrm{P}$ no solo, limitando a adsorção, portanto, pode ser usado como fertilizante e/ou condicionador de solo.

Palavras-chave: Isotermas de adsorção. Cama de aviário. Cinética. Propriedades físico-quimicas.

\footnotetext{
${ }^{*}$ Corresponding author

${ }^{1}$ Received for publication in 09/08/2020; accepted in 08/24/2021.

${ }^{2}$ Department of Agricultural Engineering, Universidade Federal de Campina Grande, Campina joselysolo@yahoo.com.br - ORCID: 0000-0002-1297-6962, lhgarofalo@hotmail.com - ORCID: edilma.dantas@hotmail.com - ORCID: 0000-0001-9663-1787, gilvanisetito@yahoo.com.br - ORCID:

Grande, PB, Brazil hugo_carvallo@hotmail.com - ORCID: 0000-0001-5468-5509. 


\section{INTRODUCTION}

Brazil stands out for its poultry production. According to the Brazilian Institute of Geography and Statistics (IBGE), in 2019 the Brazilian production of chicken carcass was 13,576.976 tons, keeping the country in the position of the world's largest exporter and the second largest producer of meat.

After disinfection, the poultry litter (PL) waste generated by the poultry sector can be reused in another poultry flock or can be used in other activities, for example as agricultural fertilizer since the poultry litter contains high levels of organic carbon (OC), nitrogen (N), phosphorus (P), potassium $(\mathrm{K})$, and other plant nutrients (GUO; SHEN; HE, 2012).

However, the soil application of PL can increase the risk of natural water pollution due to the excessive loss of various nutrients in the soluble form of PL, such as P, corroborating Guo, Shen and He (2012). These authors observed that $12-20 \%$ of the $\mathrm{P}$ in PL was water soluble and was lost in five rainfall events after soil application. To reduce the rate of $\mathrm{P}$ losses, it would be interesting to transform PL into a more stable and slow-release nutrient source, for example, biochar through the pyrolysis process, under limited air supply and temperature above $300{ }^{\circ} \mathrm{C}$. (MOHAN et al., 2014).

The conditions under which biochar is produced can influence the availability of phosphorus. According to Lehmann and Joseph (2009), the specific surface increases as a function of the pyrolysis temperature and the functional groups decrease. These changes can influence the adsorption and consequently the availability of phosphorus. There is evidence to indicate that biochar can decrease the adsorption of $\mathrm{P}$ in the soil, resulting in greater availability of the added inorganic phosphate (MORALES et al., 2013). In addition to phosphorus, it was found that the application of poultry litter biochar in an Oxisol increased the levels of potassium, calcium, magnesium, sodium and cation exchange capacity, as well as increasing the $\mathrm{pH}$ and decreasing the potential acidity of the soil (FERNANDES et al., 2018).

It is known that the adsorption of $\mathrm{P}$ in soils is controlled by the presence of iron ( $\mathrm{Fe}$ ) and aluminum (Al) oxides, which occur mainly in highly weathered soils (QAFOKU et al., 2004). One way to minimize this problem is to increase the $\mathrm{pH}$ of the soil, because this phenomenon increases the dissociation of hydroxyl $(\mathrm{OH})$ at the ends and surfaces of mineral particles or organic matter, resulting in an increase in their net negative charge and, consequently, reduction in phosphorus adsorption (FERNANDES et al., 2018). Thus, it is believed that, when applied to the soil, biochar acts as a fertilizer and, due to its alkalinity, it can act as a soil conditioner, corroborating Cui et al. (2011) and Zhai et al. (2015).
These authors demonstrated that the application of biochar in the soil increased $\mathrm{P}$ availability due to both $\mathrm{P}$ direct supply acting as a source of $\mathrm{P}$ and the reduction of $\mathrm{P}$ adsorption on Fe oxides.

However, little is known about the adsorption and/or availability of $\mathrm{P}$ after the application of poultry litter biochar to the soil. Thus, as a hypothesis, it is believed that this biochar, mainly due to the increase in soil $\mathrm{pH}$, reduces $\mathrm{P}$ adsorption, increasing the availability of $\mathrm{P}$ in the soil. According to Martinez, Espana and Diaz (2017), after eight consecutive desorptions, the Eucalyptus globulus biochar increased phosphorus release compared to the natural soil, between 78 and $84 \%$, thus promoting a greater availability of this element over time.

Phosphorus adsorption can be investigated using kinetic studies (pseudo-first and pseudosecond order) and linear and non-linear isotherms (ZHANG et al., 2015). Commonly used Langmuir and Freundlich models are useful in describing adsorption isotherms and provide effective factors in the prediction of nutrient adsorption characteristics. Thus, the aim of this study was to evaluate the process of $\mathrm{P}$ adsorption by the Ultisol incubated with different doses of poultry litter biochar through the kinetic and isothermal study.

\section{MATERIAL AND METHODS}

\section{Experiment installation and conduction}

The experiment was carried out at the Irrigation and Salinity Laboratory (ISL) of the Agricultural Engineering Department, Federal University of Campina Grande, Paraiba State (PB), Brazil, using an Ultisol collected in the Paraíba State, Brazil (070 09 '22.42' S; $35^{\circ} 52^{\prime}$ 09.64" W) in the 0$20 \mathrm{~cm}$ depth layer. Soil samples were chemically characterized according to Teixeira et al. (2017) and showed the results: $\mathrm{pH}\left(\mathrm{H}_{2} \mathrm{O}\right)=5.35 ; \mathrm{Ca}=2.78$ $\mathrm{cmol}_{\mathrm{c}} \mathrm{kg}^{-1} ; \mathrm{Mg}=1.26 \mathrm{cmol}_{\mathrm{c}} \mathrm{kg}^{-1} ; \mathrm{Na}=$ $0.11 \mathrm{cmol}_{\mathrm{c}} \mathrm{kg}^{-1} ; \mathrm{K}=0.17 \mathrm{cmol}_{\mathrm{c}} \mathrm{kg}^{-1} ; \mathrm{H}+\mathrm{Al}=$ $3.27 \mathrm{cmol}_{\mathrm{c}} \mathrm{kg}^{-1}$; organic carbon $=18.8 \mathrm{~g} \mathrm{~kg}^{-1} ; \mathrm{P}=$ $1.27 \mathrm{mg} \mathrm{kg}^{-1}$ and CEC $=7.59 \mathrm{cmol}_{\mathrm{c}} \mathrm{kg}^{-1}$.

The biochar used in this study was produced in ISL under slow pyrolysis at $350{ }^{\circ} \mathrm{C}$ from poultry litter, resulting from the rearing of broilers, with the following chemical attributes: $\mathrm{pH}=9.44 ; \mathrm{EC}=$ $7.33 \mathrm{dS} \mathrm{m}{ }^{-1} ; \mathrm{P}_{2} \mathrm{O}_{5}=4.08 \% ; \mathrm{K}_{2} \mathrm{O}=4.35 \% ; \mathrm{Ca}=$ $5.04 \% ; \mathrm{Mg}=1.28 \% ; \mathrm{S}=0.41 \% ; \mathrm{Fe}=0.72 \% ; \mathrm{Mn}=$ $0.05 \% ; \mathrm{Cu}=0.01 \% ; \mathrm{Zn}=0.05 \% ; \mathrm{B}=0.01 \%$; organic carbon $=42.22 \% ; \mathrm{C} / \mathrm{N}=18.76$ and Zero Charge Point $(\mathrm{ZCP})=8.43$. It is an amorphous, porous material, with a predominance of mediumsized pores, approximately $14.8 \mathrm{~nm}$, with a surface area of $3.37 \mathrm{~m}^{2} \mathrm{~g}^{-1}$. According to X-ray diffraction analyses, feldspar compounds [Orthoclase $\left.\left(\mathrm{KAlSi}_{3} \mathrm{O}_{8}\right)\right]$ and potassium phosphate $\left(\mathrm{K}_{2}\left(\mathrm{HPO}_{4}\right)\right)$ were identified, confirming the result of the chemical 
analysis of the biochar, which had considerable contents of $\mathrm{P}, \mathrm{K}, \mathrm{Ca}$ and $\mathrm{Mg}$. To evaluate the effect of biochar on phosphorus adsorption, the incubation method was used, placing soil samples $(0.3 \mathrm{~kg})$ in plastic bags mixed with biochar at the following doses: $\quad 0.0, \quad 12.39, \quad 24.78, \quad 37.17,49.56$ and $61.95 \mathrm{t} \mathrm{ha}^{-1}$. The calculation to determine the doses was carried out in order to raise the soil organic matter content in the arable layer (first $20 \mathrm{~cm}$ deep) from $18.8 \mathrm{~g} \mathrm{~kg}^{-1}$ (control treatment) to $25.0,31.2$, $37.4,43.6$ and $49.8 \mathrm{~g} \mathrm{~kg}^{-1}$. The incubation test was performed with four replications.

In order to promote the release of phosphorus by biochar and the neutralization of soil acidity, increasing doses of biochar were incorporated into the soil samples and incubated for a period of 60 days, keeping their moisture at around $70 \%$ with the addition of deionized water. After this period, these samples were used in the kinetic and phosphorus adsorption study.

\section{Phosphorus adsorption kinetics}

To evaluate the adsorption kinetics of $\mathrm{P}, 400$ $\mathrm{ml}$ of $52.5 \mathrm{mg} \mathrm{L}^{-1}$ solution of $\mathrm{P}$ in were added Erlenmeyer flask containing $5 \mathrm{~g}$ of soil incubated with different doses of biochar. The samples were left on a horizontal shaker at $120 \mathrm{rpm}$, at $25 \pm 2{ }^{\circ} \mathrm{C}$ for 48 hours. During this period, 20-ml aliquots of the samples were taken at the intervals $0.1,0.2,0.3$, $0.5,1.1,1.5,2.0,3.0,6.0,12.0,24.0$ and $48.0 \mathrm{~h}$, filtered and, by colorimetry, $\mathrm{P}$ was measured according to Braga and Defelipo (1972). The experiment was carried out in duplicate.

The efficiency of the process was determined according to Equation 1 and the amount of adsorbed metal was calculated according to Equation 2.

$$
\begin{gathered}
\mathrm{T}=\frac{\left(C_{o}-C_{t}\right) 100}{C_{o}} \\
\mathrm{q}_{\mathrm{e}}=\frac{\left(C_{o}-C_{t}\right) V}{m}
\end{gathered}
$$

where: $\mathrm{T}$ is the phosphate ion removal rate (\%); $\mathrm{C}_{\mathrm{o}}$ is the initial concentration of the phosphate ion in the solution $\left(\mathrm{mg} \mathrm{L}^{-1}\right) ; \mathrm{C}_{\mathrm{t}}$ is the equilibrium concentration of phosphate ions after adsorption $\left(\mathrm{mg} \mathrm{L}^{-1}\right)$; qe is the amount adsorbed by mass of adsorbent $\left(\mathrm{mg} \mathrm{g}^{-1}\right)$; $\mathrm{V}$ is the volume of effluent $(\mathrm{L}) ; \mathrm{m}$ is the mass of the adsorbent (g).

To represent the experimental kinetic data of phosphorus adsorption by the incubated soil, the kinetic models of pseudo-first (LAGERGREN, 1898) and pseudo-second order (HO; WASE; FORSTER, 1996) were used, according to Equations 3 and 4 , respectively.

$$
\begin{aligned}
& \mathrm{q}_{\mathrm{t}}=\mathrm{q}_{\mathrm{e}}(1-e)^{-K_{1} t} \\
& \mathrm{q}_{\mathrm{t}}=\frac{q e^{2} K_{2} t}{1+q_{e} K_{2} t}
\end{aligned}
$$

where: $K_{1}$ and $K_{2}$ are the adsorption rate constants of pseudo-first $\left(\mathrm{h}^{-1}\right)$ and pseudo-second order $\left(\mathrm{g} \mathrm{mg}^{-1} \mathrm{~h}^{-1}\right)$, respectively; qt is the amount adsorbed per gram of adsorbent at any time $\mathrm{t}(\mathrm{h})\left(\mathrm{mg} \mathrm{g}^{-1}\right)$, qe is the amount adsorbed per gram of adsorbent at equilibrium ( $\left.\mathrm{mg} \mathrm{g}^{-1}\right)$ and $\mathrm{t}$ represents time $(\mathrm{h})$. The values of qe, $\mathrm{K}_{1}$ and $\mathrm{K}_{2}$ were estimated using the non -linear regression method, using a SOLVER tool, following the sum of squared errors methodology (FOO; HAMEED, 2010).

\section{Adsorption isotherm}

The remaining phosphorus (Prem) was determined by stirring a solution of $60 \mathrm{mg} \mathrm{L}^{-1}$ of $\mathrm{P}$ in $0.01 \mathrm{~mol} \mathrm{~L}^{-1} \mathrm{CaCl}_{2}$ at $120 \mathrm{rpm}$, for one hour, in a 1:10 ratio of soil:solution (ALVAREZ; FONSECA, 1990). After stirring, the solid and liquid phases were separated, and the concentration of $\mathrm{P}$ was determined in the equilibration solution, using the ascorbic acid method, modified by Braga and Defelipo (1972). The doses for determining the Maximum Phosphorus Adsorption Capacity (MPAC) were calculated based on the Prem content and ranged from 0 to $150 \mathrm{mg} \mathrm{L}^{-1}$ (ALVAREZ; FONSECA, 1990). After 24 hours of stirring, the samples were filtered and the phosphorus in the equilibration solution was quantified by colorimetry (BRAGA; DEFELIPO, 1972).

To describe the $\mathrm{P}$ adsorption phenomenon, the Langmuir (Equation 5) and Freundlich (Equation 6) equations were used

$$
\begin{aligned}
& \mathrm{q}_{\mathrm{e}}=\frac{q_{m} C K_{l}}{1+K_{l} C} \\
& \mathrm{q}_{\mathrm{e}}=K_{f} C^{1 / \mathrm{n}}
\end{aligned}
$$

where: $\mathrm{q}_{\mathrm{e}}$ is the amount adsorbed at equilibrium $\left(\mathrm{mg} \mathrm{\textrm {g } ^ { - 1 }}\right), \mathrm{C}$ is the concentration of adsorbate at equilibrium (mg L $\left.\mathrm{L}^{-1}\right), \mathrm{q}_{\mathrm{m}}$ corresponds to the maximum adsorption capacity $\left(\mathrm{mg} \mathrm{g}^{-1}\right), 1 / \mathrm{n}$ is the constant related to the surface heterogeneity, and $\mathrm{K}_{1}$ and $\mathrm{K}_{\mathrm{f}}$ are the Langmuir adsorption energy constants $\left(\mathrm{L} \mathrm{mg}^{-1}\right)$ and the Freundlich adsorption capacity constant $\left(\mathrm{L} \mathrm{mg}^{-1}\right)$, respectively.

\section{Statistical analysis}

For the phosphorus removal rate, the splitting of biochar doses within each level of phosphorus 
added was analyzed by the Scott-Knott test using the SISVAR 5.7 statistical software. The fit of equations 1 and 2 to the experimental data was performed by non-linear regression using the Microsoft Office Excel SOLVER tool, following the sum of squared errors methodology, which represents the sum of the squared differences between the experimental and calculated values (FOO; HAMEED, 2010).

The quality of the fits of the adsorption and kinetic models was determined by comparing the values of the determination coefficients $\left(\mathrm{R}^{2}\right)$ and sum of squared errors (SSE). The models with the highest $\mathrm{R}^{2}$ and the lowest SSE were considered the most suitable to describe the adsorption and kinetic processes.

\section{RESULTS AND DISCUSSION}

\section{Phosphorus sorption}

The highest rates of $\mathrm{P}$ removal, after 24 hours, regardless of the concentration of $\mathrm{P}$ applied, were obtained using the soil in the absence of biochar, whose removals were greater than $60 \%$ up to the addition of $52.5 \mathrm{mg} \mathrm{L}^{-1}$ of $\mathrm{P}$ (Figure 1).

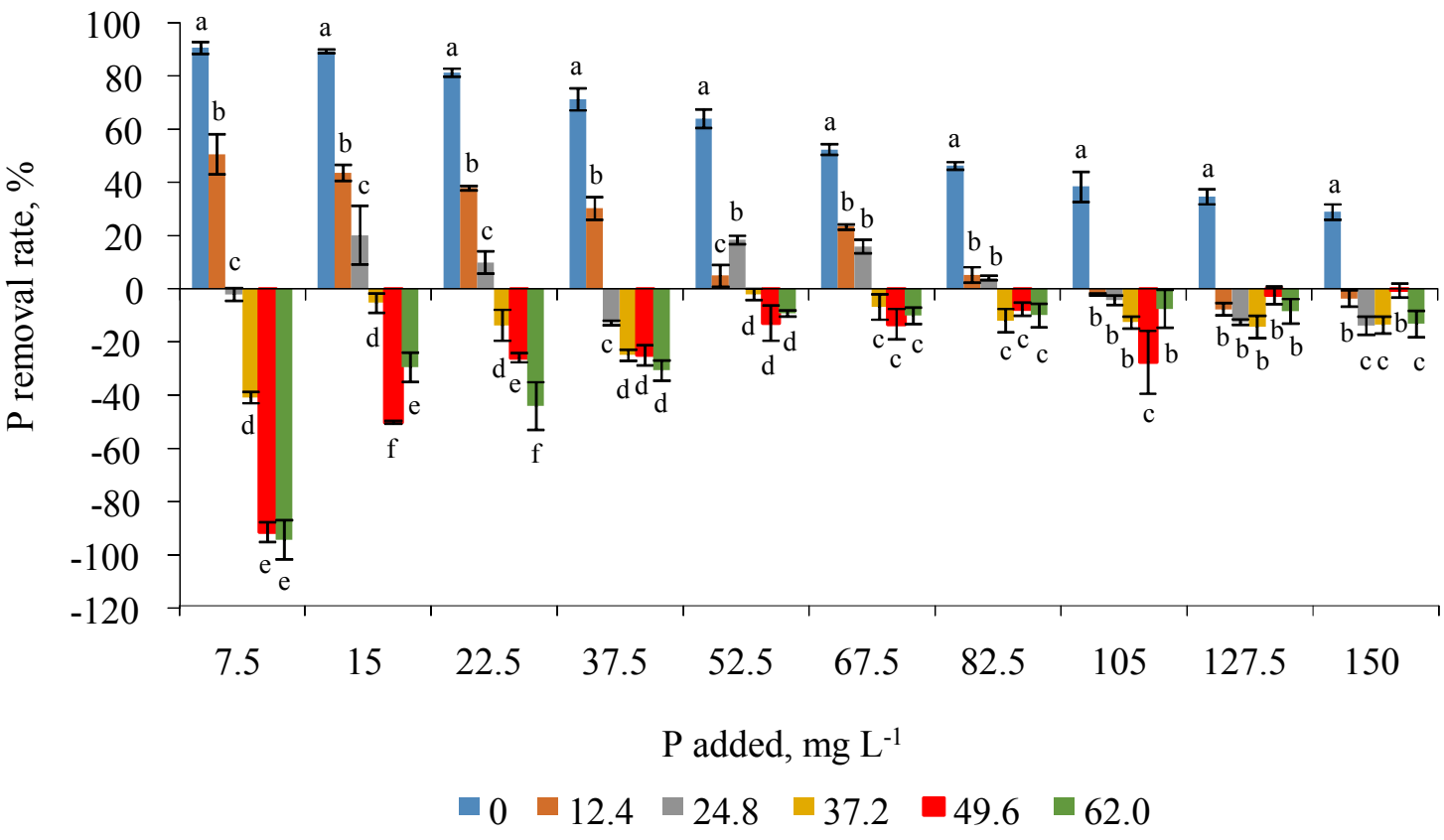

Biochar dose, $\mathrm{t} \mathrm{ha}^{-1}$

Figure 1. Rates of $P$ removal at different concentrations used in the study of adsorption by soil incubated with biochar doses, after 24 hours of stirring. Means followed by the same lowercase letter indicate that the doses of biochar do not differ from each other within the same concentration of $\mathrm{P}$. Vertical bars represent the standard errors for means of each treatment $(n=4)$.

The capacity of the soil to remove $\mathrm{P}$ varied with the doses of biochar and its concentrations in the treatment solutions. In general, the rate of $\mathrm{P}$ removal decreased from the moment the soil was incubated with biochar, assuming negative values, regardless of the concentration of $\mathrm{P}$ added, with the use of biochar doses greater than $24.8 \mathrm{t} \mathrm{ha}^{-1}$. This behavior indicates that the soil with these doses was not able to remove $\mathrm{P}$ because, above these doses, the concentration of $\mathrm{P}$ in the equilibrium solution exceeded the capacity of the soil to remove $\mathrm{P}$, so it remained in the solution.

With the increase in the concentration of $\mathrm{P}$ in solution, there was a decrease in the removal of $\mathrm{P}$ with the use of the highest doses of biochar (Figure 1). This occurred probably for the same reason as before, that is, the soil removal capacity also decreased with the increase of the concentration of $\mathrm{P}$ in the soil solution ( $\mathrm{P}$ added by the treatment solution $+\mathrm{P}$ released by the biochar), increasing the $\mathrm{P}$ in equilibrium. Taking as an example the application of $150 \mathrm{mg} \mathrm{L}^{-1}$ of $\mathrm{P}$, the remaining $\mathrm{P}$ concentration corresponded to $106.64,155.50$, $173.33,170.36,150.96$ and $169.89 \mathrm{mg} \mathrm{L}^{-1}$ of $\mathrm{P}$ with the application of $0,12.4,24.8,37.2,49.6$ and $62.0 \mathrm{t} \mathrm{ha}^{-1}$ of biochar, respectively. In this case, only in the control treatment (absence of biochar) was $\mathrm{P}$ removed, thus characterizing the adsorption of this element by the adsorbent (soil). These results corroborate Yao et al. (2011), who demonstrated that biochar without pre-treatment (without chemical modifications) has a very high negative zeta potential, so anions from $\mathrm{P}$, such as phosphate, are not adsorbed. 
Increase in the availability of $\mathrm{P}$, after the application of biochar, was also reported by Bai et al. (2015), who found a significant increase in the release of $\mathrm{P}$ to the soil, approximately 1000 times, with the application rate of $10 \mathrm{t} \mathrm{ha}^{-1}$ of poultry litter biochar.

Although most studies have shown that biochar can increase the $\mathrm{P}$ content in the soil due to the direct supply of $\mathrm{P}$ acting as a source of $\mathrm{P}$ and/or the reduction of $\mathrm{P}$ adsorption on $\mathrm{Fe}$ oxides (CUI et al., 2011; ZHAI et al., 2015), some studies have shown that there is no significant effect and others have shown that biochar can even reduce the available $P$ in the soil, probably due to the characteristics of the raw material used in its production.

So far, variations in the availability of $\mathrm{P}$ in soils altered by biochar are not clearly understood. However, it is reasonable to state that the impact of biochar on the availability of $\mathrm{P}$ in soils is affected by the characteristics inherent to the biochar (for example, pyrolysis temperature, presence of functional groups, total $\mathrm{P}$ content, $\mathrm{pH}$, among others) and the characteristics of the soil, such as soil $\mathrm{pH}$, inorganic and organic soil $\mathrm{P}$, clay minerals, ionic strength and native microbial diversity.

In this work, the pyrolysis temperature used, $350^{\circ} \mathrm{C}$, for the production of poultry litter biochar may have influenced the availability of phosphorus. Zhang et al. (2016) evaluated the influence of nine biochars and different pyrolysis temperatures and found that the biochar of blady grass (Imperata cylindrica) at $450{ }^{\circ} \mathrm{C}$ was the one that promoted the highest amount of $\mathrm{P}$ available in the soil and only the biochar derived from Mallee (Eucalyptus polybractea) at $720{ }^{\circ} \mathrm{C}$ showed an extraordinary $\mathrm{P}$ adsorption capacity. Glaser and Lehr (2019) reported that biochar produced at temperatures above $600{ }^{\circ} \mathrm{C}$ did not promote a significant effect on the availability of $\mathrm{P}$; however, the same behavior was not observed when pyrolysis was performed between 450 and $600{ }^{\circ} \mathrm{C}$, where the availability of $\mathrm{P}$ increased significantly in soils incubated with biochar.

The rate of phosphate removal by the soil incubated with different doses of biochar for $48 \mathrm{~h}$ is shown in Figure 2. In this study, the concentration of $\mathrm{P}$ used was $52.5 \mathrm{mg} \mathrm{L}^{-1}$. It can be seen that, among the various treatments, only the soil samples incubated with the first three doses of biochar showed a positive phosphate removal capacity. However, as seen in the sorption study, there was a decrease in phosphate retention due to the application of biochar; in decreasing order the highest rates were $30.62,14.08$ and $14.08 \%$ for treatments $0,12.4$ and $24.8 \mathrm{t} \mathrm{ha}^{-1}$, respectively. At other doses of biochar, that is, 37.2, 49.6 and $62.0 \mathrm{t} \mathrm{ha}^{-1}$, the phosphate retention was negative since the concentration of this anion increased compared to the initial concentration after the end of the reaction $(48 \mathrm{~h})$, whose means were $55.43,53.08$ and $60.13 \mathrm{mg} \mathrm{L}^{-1}$, respectively. This increase was probably due to the blocking of soil adsorption sites and the release of $\mathrm{P}$ promoted by biochar.

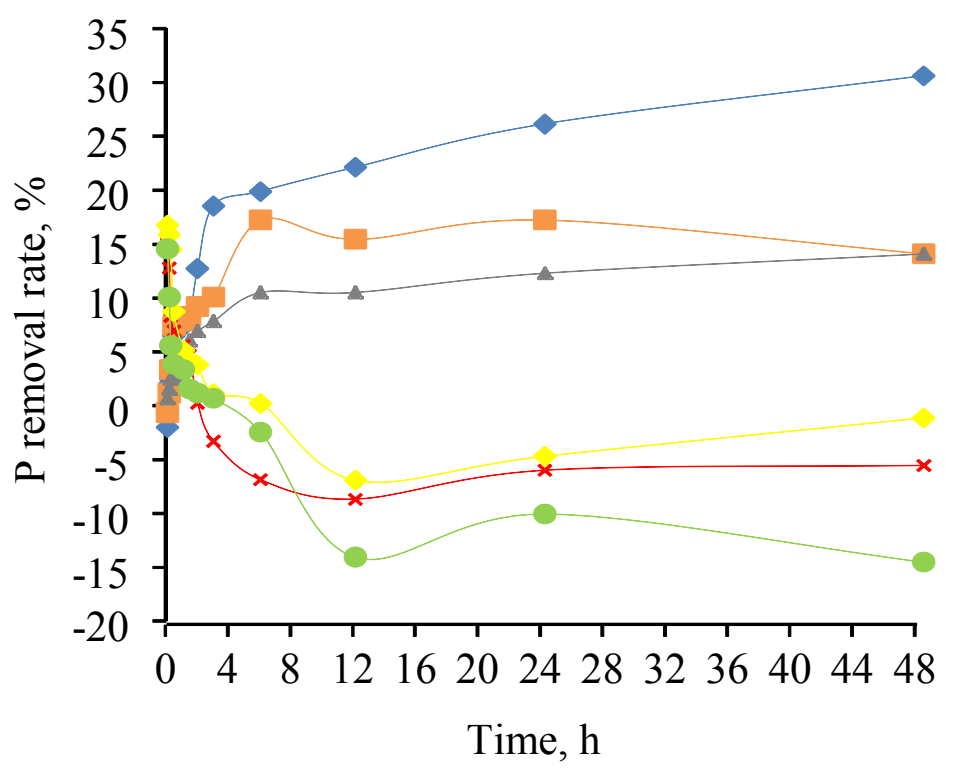

$$
\square=12.4 \square 24.8 \square 37.2 \square 49.6 \square 62.0
$$

$$
\text { Biochar dose, } \mathrm{t} \mathrm{ha}^{-1}
$$

Figure 2. Phosphorus removal rate over time as a function of the application of different biochar doses 


\section{Phosphorus adsorption kinetics}

The adsorption behavior of $\mathrm{P}$ as a function of contact time in treatments $0,12.4$ and $24.8 \mathrm{t} \mathrm{ha}^{-1}$ of biochar was investigated through kinetic studies (Figure 3). Regardless of the treatment, the $\mathrm{P}$ adsorption process was fast in the initial stage of the reaction due to a high number of binding sites available for adsorption (GHAEDI; HASSANZADEH; KOKHDAN, 2011), then the rate gradually decreased with the contact time until reaching equilibrium, which occurred within $6 \mathrm{~h}$. This time was similar to that observed by Qian et al. (2013), who reported that approximately half of the
$\mathrm{P}$ is released as orthophosphate and pyrophosphate at a $\mathrm{pH}$ of 9 in the first 8 hours.

Also according to Figure 3, the phosphorus adsorption kinetics (qt) decreased as a function of increasing doses of biochar $\left(0,12.4\right.$ and $\left.24.8 \mathrm{tha}^{-1}\right)$, as can be seen, respectively, in the sequence of this figure, A, B and C. This is because, once applied to the soil, biochar releases phosphorus instantly and slowly in the long term, corroborating $\mathrm{Li}$ et al. (2019). The order of the amount of adsorption in equilibrium, observed in this study, was consistent with the results of the sorption experiments, corroborating that the soil in the absence of biochar has the highest $\mathrm{P}$ adsorption capacity.

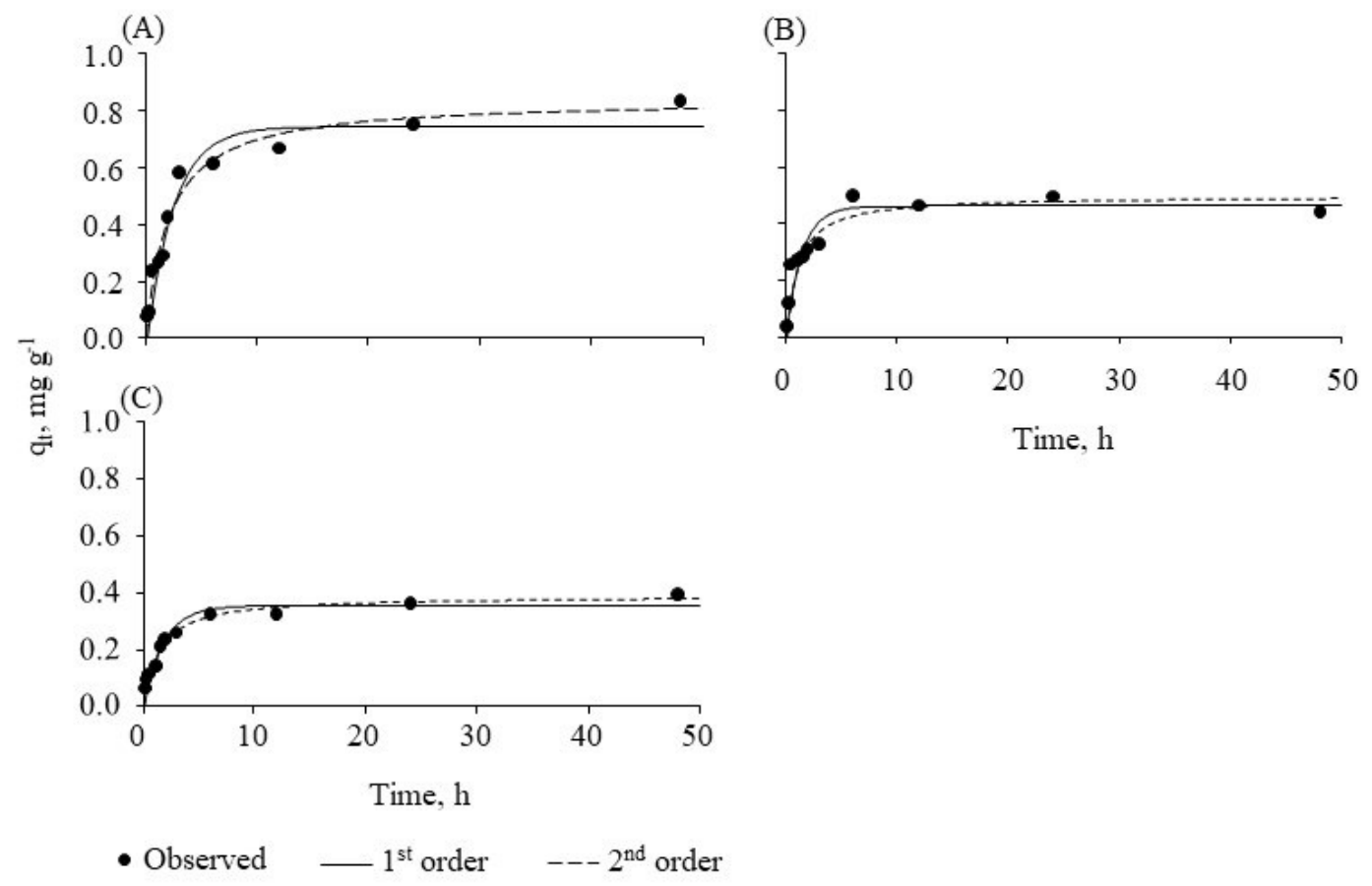

Figure 3. $\mathrm{P}$ adsorption kinetics in soil incubated with $0 \mathrm{t} \mathrm{ha}^{-1}(\mathrm{~A}), 12.4 \mathrm{tha}^{-1}(\mathrm{~B})$ and $24.8 \mathrm{tha}^{-1}$ (C) of biochar.

From the curves obtained for the first- and second-order kinetic models, the relevant calculations were performed to obtain the parameters related to the biochar's adsorption kinetics in relation to the studied ion, that is, the values of the velocity constants, adsorption $(\mathrm{k})$, concentration of metal adsorbed in equilibrium (qe), the coefficient of determination $\left(\mathrm{R}^{2}\right)$ and the sum of the squared errors (SSE), calculated from the graphs generated for both kinetic models (Table 1), were obtained.

Table 1. Parameters of $\mathrm{P}$ adsorption kinetics as a function of biochar doses

\begin{tabular}{|c|c|c|c|c|c|c|c|c|}
\hline \multirow{3}{*}{$\begin{array}{l}\text { Biochar application } \\
\qquad \mathrm{t} \mathrm{ha}^{-1}\end{array}$} & \multicolumn{4}{|c|}{ Pseudo-first order } & \multicolumn{4}{|c|}{ Pseudo-second order } \\
\hline & $\mathrm{q}_{\mathrm{e}}$ & $\mathrm{K}_{1}$ & \multirow{2}{*}{$\mathrm{R}^{2}$} & \multirow{2}{*}{ SSE } & $\mathrm{q}_{\mathrm{e}}$ & $\mathrm{K}_{2}$ & \multirow{2}{*}{$\mathrm{R}^{2}$} & \multirow{2}{*}{ SSE } \\
\hline & $\mathrm{mg} \mathrm{g}^{-1}$ & $\mathrm{~h}^{-1}$ & & & $\mathrm{mg} \mathrm{g}^{-1}$ & $\mathrm{~g} \mathrm{mg}^{-1} \mathrm{~h}^{-1}$ & & \\
\hline 0 & 0.747 & 0.414 & 0.958 & 0.046 & 0.839 & 0.583 & 0.969 & 0.036 \\
\hline 12.4 & 0.463 & 0.701 & 0.926 & 0.031 & 0.497 & 2.075 & 0.940 & 0.026 \\
\hline 24.8 & 0.355 & 0.556 & 0.972 & 0.007 & 0.388 & 1.900 & 0.986 & 0.003 \\
\hline 37.2 & - & - & - & - & - & - & - & - \\
\hline 49.6 & - & - & - & - & - & - & - & - \\
\hline 62.0 & - & - & - & - & - & - & - & - \\
\hline
\end{tabular}


As shown in Table 1, both kinetic models fitted to the experimental data; however, considering the values of the determination coefficient $\left(\mathrm{R}^{2}\right)$ and the sum of squared errors (SSE), the experimental results of kinetic adsorption, regardless of the dose of biochar, are better explained in terms of the pseudo-second order model, corroborating Wang et al. (2018) and Jung et al. (2015). Based on this model, the calculated values of qe were close to the experimental values $(0.839,0.443$ and 0.397 for doses of $0,12.4$ and $24.8 \mathrm{t} \mathrm{ha}^{-1}$, respectively, after $48 \mathrm{~h}$ ) and also the values of $\mathrm{R}^{2}$ were close to 1.0 .

The pseudo-second order model assumes chemosorption as the predominant stage of the kinetic mechanism of adsorption, involving chemical interactions that lead to the formation of chemical compounds or adsorption complex on the surface of the adsorbent material (OFOMAJA; NAIDOO; MODISE, 2010). In this case, adsorption is related to the concentration of the adsorbent in solution and to the adsorbent adsorption sites, suggesting that the adsorption speed is dependent on the adsorption capacity in equilibrium and not only on the adsorbate concentration.

Regarding the concentration of $\mathrm{P}$ adsorbed in equilibrium (qe), there was a decrease in its values with the increase in the applied dose of biochar; such result indicates that the biochar reduces the $\mathrm{P}$ adsorption capacity of the soil. However, this information can only be confirmed by the results obtained from the equilibrium studies, presented later.

(A)

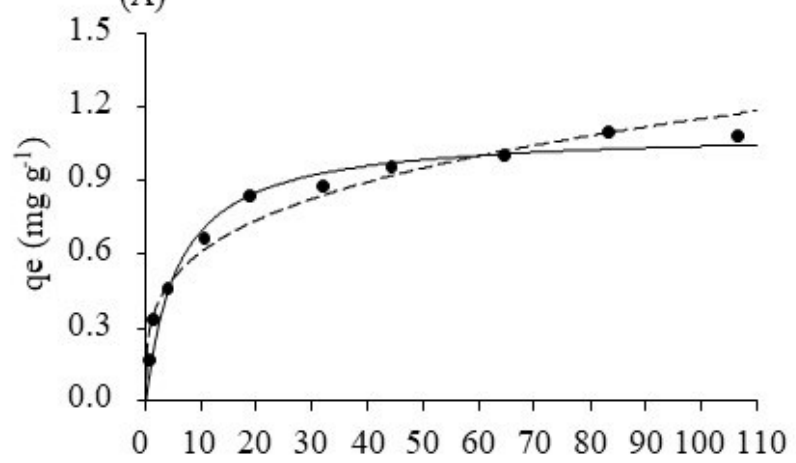

Still in relation to Table 1, it appears that the biochar promoted an increase in the adsorption speed $(\mathrm{k})$. This behavior is due to the concentration of $\mathrm{P}$ present in the biochar, equal to $40.8 \mathrm{~g} \mathrm{~kg}^{-1}$ of total $\mathrm{P}$. The adsorption rate increased with the use of biochar due to the release of $\mathrm{P}$ in the equilibrium solution; however, despite the higher values of $(\mathrm{k})$, adsorption sites were blocked by the biochar, decreasing the adsorbed concentration.

\section{Adsorption isotherm}

Isotherms are mathematical models that describe an adsorption system. Through these models it is possible to evaluate interactions between the material that adsorbs (adsorbent) and the ion that is adsorbed (adsorbate), the ion being retained on the solid interface. In this study, the adsorbent was the soil in the absence of biochar and the one incubated with $12.4 \mathrm{t} \mathrm{ha}^{-1}$ because, as verified in the previous topic on sorption, the release exceeded the adsorption in the treatment of soil $+24.8 \mathrm{t} \mathrm{ha}^{-1}$ of biochar with the addition of the following concentrations: $7.5, \quad 37.5, \quad 105.0, \quad 127.5$ and $150.0 \mathrm{mg} \mathrm{L}^{-1}$ of $\mathrm{P}$. At the other doses, sorption was not observed regardless of the added concentration.

The $\mathrm{P}$ adsorption isotherms were obtained by the relationship between the amount of $\mathrm{P}$ adsorbed (qe, $\mathrm{mg} \mathrm{g}^{-1}$ ) and the equilibrium concentration (Ce, $\mathrm{mg} \mathrm{L}^{-1}$ ). These isotherms for treatments 0 and $12.4 \mathrm{t} \mathrm{ha}^{-1}$ of biochar were evaluated by fitting with the Langmuir and Freundlich models (Figures 4A and 4B).

(B)

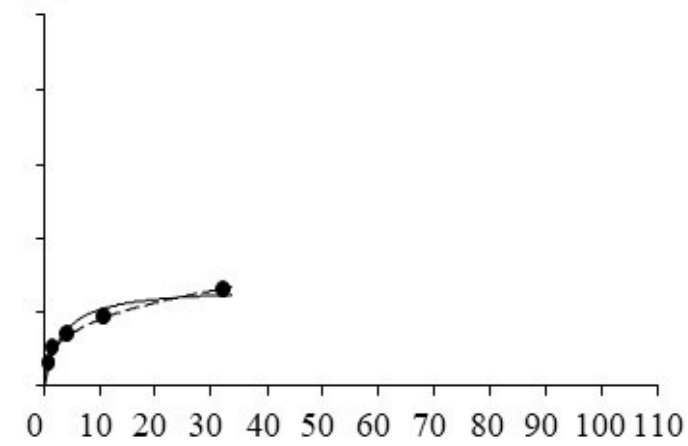

\section{$\mathrm{Ce}\left(\mathrm{mg} \mathrm{L}^{-1}\right)$ \\ - Observed _ Langmuir ---Freundlich}

Figure 4. $\mathrm{P}$ adsorption isotherms in the soil incubated with $0 \mathrm{tha}^{-1}(\mathrm{~A})$ and $12.4 \mathrm{tha}^{-1}(\mathrm{~B})$ of biochar.

Still analyzing Figures $4 \mathrm{~A}$ and $4 \mathrm{~B}$, it was noticed that the adsorption isotherms, regardless of the applied biochar dose, showed a concave curvature in relation to the abscissa, indicating that the adsorption was favorable, with the adsorbent surface having a high affinity for the ion in study, even under conditions of low concentration in the solution. There was also a decrease in the availability of adsorption sites with the increase in the concentration of the solution.

The values of the maximum phosphorus adsorption capacity (qmax) and the adsorption 
energy constant $(\mathrm{Kl})$ for the Langmuir isotherm, the adsorption capacity constant (Kf) and the constant (n) for the Freundlich isotherm, the coefficients for determining the equations and the sum of the squared errors (SSE) of the models are shown in Table 2.

The Langmuir and Freundlich isothermal models were fitted to the $\mathrm{P}$ adsorption data. Regardless of the applied dose, both models described the $\mathrm{P}$ adsorption patterns well, evidenced by the high values of determination coefficient $\left(\mathrm{R}^{2}\right)$ and low values of sum of squared errors (SSE). However, in the absence of biochar treatment, the Langmuir model showed the highest coefficient of determination (0.986) and the lowest sum of squared errors $(0.022)$, showing that $\mathrm{P}$ adsorption was better described by this model, assuming that sorption was uniform on all the binding sites. With the application of $12.4 \mathrm{t} \mathrm{ha}^{-1}$ of biochar, the Freundlich model showed an $\mathrm{R}^{2}$ equal to 0.993 and an SSE of 0.0007 , indicating that the adsorption occurred with the formation of multilayers, instead of just one monolayer, and that affinity for adsorption sites decreased exponentially with increased saturation
(PAUL, 2013).

The maximum phosphorus adsorption capacity (qmax) decreased with the use of biochar, from $1.105 \mathrm{mg} \mathrm{g}^{-1}$ (absence of biochar) to $0.402 \mathrm{mg} \mathrm{g}^{-1}$ (soil plus $12.4 \mathrm{t} \mathrm{ha}^{-1}$ of biochar), which represented a $63.62 \%$ reduction in the capacity of the soil to adsorb phosphorus (Table 2). Unlike qmax, the Langmuir binding energy (KL) increased as a function of the application of the biochar, from 0.174 to $0.328 \mathrm{~L} \mathrm{mg}^{-1}$ with doses 0 and $12.4 \mathrm{t} \mathrm{ha}^{-1}$, respectively, indicating that at the lowest incubation rates the $\mathrm{P}$ was adsorbed more strongly by the incubated soil. However, this result is not conclusive, because only at the lowest dose of application of biochar was it possible to determine the isotherms and, even so, adsorption occurred only at 5 of the 10 concentrations added. Novais et al. (2018) also using biochar from poultry litter pyrolyzed at $350{ }^{\circ} \mathrm{C}$, found values of qmax higher than that observed in this study, which corresponded to $250 \mathrm{mg} \mathrm{g}^{-1}$, but the authors only verified adsorption by the biochar after doping with $\mathrm{MgCl}_{2}$.

Table 2. Parameters of the $\mathrm{P}$ adsorption isotherm according to the application of biochar for the Langmuir and Freundlich models (SSE $=$ Sum of squared errors).

\begin{tabular}{|c|c|c|c|c|c|c|c|c|c|}
\hline \multirow{2}{*}{$\begin{array}{c}\text { Biochar } \\
\text { application } \\
\text { t ha }^{-1}\end{array}$} & \multirow{2}{*}{$\mathrm{pH}$} & \multicolumn{4}{|c|}{$\begin{array}{l}\text { Parameters estimated by } \\
\text { Langmuir equation }\end{array}$} & \multicolumn{4}{|c|}{$\begin{array}{l}\text { Parameters estimated by } \\
\text { Freundlich equation }\end{array}$} \\
\hline & & $\frac{\mathrm{q}_{\mathrm{m}}}{\mathrm{mg} \mathrm{g}^{-1}}$ & $\frac{\mathrm{K}_{\mathrm{L}}}{\mathrm{L} \mathrm{mg}^{-1}}$ & $\mathrm{R}^{2}$ & SSE & $\frac{\mathrm{K}_{\mathrm{f}}}{\mathrm{L} \mathrm{mg}^{-1}}$ & $\mathrm{n}$ & $\mathrm{R}^{2}$ & SSE \\
\hline 0 & 5.20 & 1.105 & 0.174 & 0.986 & 0.022 & 0.017 & 3.614 & 0.972 & 0.042 \\
\hline 12.4 & 5.56 & 0.402 & 0.328 & 0.971 & 0.003 & 0.002 & 3.087 & 0.993 & 0.0007 \\
\hline 24.8 & 5.92 & - & - & - & - & - & - & - & - \\
\hline 37.2 & 6.20 & - & - & - & - & - & - & - & - \\
\hline 49.6 & 6.35 & - & - & - & - & - & - & - & - \\
\hline 62.0 & 6.50 & - & - & - & - & - & - & - & - \\
\hline
\end{tabular}

The decrease in $\mathrm{P}$ adsorption may be related to the increase in soil $\mathrm{pH}$ after the application of biochar, corroborating Cui et al. (2011). In Table 2, it can be seen that in the control treatment the soil $\mathrm{pH}$ was 5.20 , but its value increased proportionally with the use of biochar, reaching its highest (6.50) with the use of $49.8 \mathrm{~g} \mathrm{~kg}^{-1}$. The Ultisol used in this study, for being very weathered, has its electrical charges dependent on $\mathrm{pH}$, so the increase of this attribute with the use of biochar increased the content of negative net charge in the soil and consequently decreased the adsorption of phosphorus.

According to Wei et al. (2013), the labile P concentration of the biochar increases proportionally with the acidity of the soil. When the $\mathrm{pH}$ of the soil increases in response to the addition of biochar, the increase in the negative charge on the mineral surface of the soil favors the decrease in the adsorption of P (MURPHY; STEVENS, 2010). As a result, there is an increase in the availability of phosphorus in the soil (CUI et al., 2011). This occurs when $\mathrm{Ca}$ and $\mathrm{Mg}$ activities are low enough to prevent
Ca / Mg-P precipitation (QIAN et al., 2013).

Still in relation to Table 2 , it is observed that the adsorption capacity (Kf) and the Freundlich constant $(n)$ were greater in the treatment with absence of biochar, 0.017 and 3.614, respectively. According to Kim et al. (2018), $n$ values between 1 and 10 indicate that the adsorption was effective and, as the $\mathrm{Kf}$ value increases, the affinity of the adsorbate for the adsorbent increases. These results demonstrate that the Ultisol used in this study, when incubated, has a smaller sorption site for $P$. Mahadevan et al. (2018) reported that the $n$ values varied from 0.7 to 2.5 for the removal of $\mathrm{P}$ by the bentonite-alum system. According to Novais et al. (2018), the $n$ values ranged from 1 to 3 for adsorption of $\mathrm{P}$ in poultry litter biochar and sugarcane bagasse.

Despite the fact that the poultry litter biochar used in this study has characteristics that could promote an adsorption of $\mathrm{P}$ such as surface area $\left(3.37 \mathrm{~m}^{2} \mathrm{~g}^{-1}\right)$ and presence of mesopores, such characteristics did not increase its adsorptive 
capacity for the ion phosphate. On the contrary, an increase in $\mathrm{P}$ available to the soil was observed as a function of biochar doses, probably due to its alkaline character, increasing the presence of negative charges in the soil, and due to the release of $\mathrm{P}$ from its composition to the soil. The isothermal and kinetic results of this study suggest that the application of biochar decreases the phosphorus adsorption capacity of the Ultisol and increases the concentration of remaining $\mathrm{P}$, which is promising from an agronomic point of view as it increases the availability of this nutrient to crops

\section{CONCLUSIONS}

The highest phosphorus adsorption capacity in the soil was $1.105 \mathrm{mg} \mathrm{g}^{-1}$, confirming the kinetic study, where there was a decrease in adsorption, proportionally due to the application of biochar, whose released concentration surpassed the adsorbed one, incubating the soil with $37.2,49.6$ and $62.0 \mathrm{t} \mathrm{ha}^{-1}$.

The Langmuir model was better at describing the adsorption of $\mathrm{P}$ by the soil in treatments with 0 and $12.4 \mathrm{tha}^{-1}$ of biochar.

The pseudo-second order model fitted well to the adsorption kinetics of $\mathrm{P}$, showing that the adsorption is controlled chemically.

Considering that, in weathered soils with low $\mathrm{P}$ content, poultry litter biochar could be used as fertilizer and as soil conditioner, increasing the availability of $\mathrm{P}$ to the soil.

\section{REFERENCES}

ALVAREZ, V. V. H.; FONSECA, D. M. Definição de doses de fósforo para determinação da capacidade máxima de adsorção de fosfatos e para ensaios em casa de vegetação. Revista Brasileira Ciência do Solo, 14: 49-55, 1990.

BAI, S. H. et al. Soil and foliar nutrient and nitrogen isotope composition (delta $\mathrm{N}-15$ ) at 5 years after poultry litter and green waste biochar amendment in a macadamia orchard. Environmental Science and Pollution Research, 22: 3803-3809, 2015.

BRAGA, J. M.; DEFELIPO, B. V. Relações entre formas de fósforo inorgânico, fósforo disponível e material vegetal em solos sob vegetação de cerrado: I - Trabalhos de laboratório. Ceres, 19: 124-136, 1972.

CUI, H. et al. Enhancing phosphorus availability in phosphorus-fertilized zones by reducing phosphate adsorbed on ferrihydrite using rice straw-derived biochar. Journal of Soils and Sediments, 11: 11351141, 2011.

FERNANDES, J. D. et al. Soil chemical amendments and the macronutrients mobility evaluation in Oxisol treated with biochar. Journal of Agricultural Science, 10: 238-247, 2018.

FOO, K. Y.; HAMEED, B. H. Insights into the modeling of adsorption isotherm systems. Chemical Engineering Journal, 156: 2-10, 2010.

GHAEDI, M.; HASSANZADEH, A.; KOKHDAN, S. N. Multiwalled carbon nanotubes as adsorbents for the kinetic and equilibrium study of the removal of alizarin red s and morin. Journal of Chemical \& Engineering Data, 56: 2511-2520, 2011.

GUO, M.; SHEN, Y.; HE, Z. Poultry litter-based biochar: preparation, characterization, and utilization. In: HE, Z. (Ed.). Applied research of animal manure: challenges and opportunities beyond the adverse environmental concerns. New York, NY: Nova Science, 2012. v .1, cap. 8, p. 169202.

GLASER, B.; LEHR, V. Biochar effects on phosphorus availability in agricultural soils: A metaanalysis. Scientific Reports, 9: 1-9, 2019.

HO,Y. S.; WASE, D.A.J.; FORSTER, C. F. Kinetic studies of competitive heavy metal adsorption by sphagnum moss peat. Environmental Technology, 17: 71-77, 1996.

JUNG, K. W. et al. Kinetic study on phosphate removal from aqueous solution by biochar derived from peanut shell as renewable adsorptive media. International Journal of Environmental Science and Technololy, 12: 3363-3372, 2015.

KIM, K. et al. Quantitative measurement on removal mechanisms of phosphate by class-F fly ash. International Journal of Coal Preparation and Utilization, 38: 1-12, 2018.

LAGERGREN, S. To the theory of so-called adsorption dissolved substances. The Royal Swedish Academy Science, 24: 1-39, 1898.

LEHMANN, J.; JOSEPH, S. Biochar for Environmental Management: Science and Technology. 1. ed. London (GB): Routledge, 2009. $448 \mathrm{p}$.

LI, F. et al. Effects of biochar amendments on soil phosphorus transformation in agricultural soils. Advances in Agronomy, 158: 131-172, 2019. 
MAHADEVAN, H. et al. Optimization of retention of phosphate species onto a novel bentonite-alum adsorbent system. Environmental Technology \& Innovation, 9: 1-15, 2018.

MARTINEZ, M. J.; ESPANA, J. C.; DIAZ, J. D. J. Effect of Eucalyptus globullus biochar addition on the availability of phosphorus in acidic soil. Agronomía Colombiana, 35: 75-81, 2017.

MOHAN, D. et al. Organic and inorganic contaminants removal from water with biochar, a renewable, low cost, and sustainable adsorbent Acritical review. Bioresource Technology, 160: 191 $-202,2014$.

MORALES, M. M. et al. Sorption and desorption of phosphate on biochar and biochar-soil mixtures. Soil Use and Management, 29:1-9, 2013.

MURPHY, P. N. C.; STEVENS, R. J. Lime and gypsum as source measures to decrease phosphorus loss from soils to water. Water Air and Soil Pollution, 212: 101-111, 2010.

NOVAIS, S. V. et al. Poultry manure and sugarcane straw biochars modified with $\mathrm{MgCl}_{2}$ for phosphorus adsorption. Journal of Environmental Management, 214: 36-44, 2018.

OFOMAJA, A. E.; NAIDOO, E. B.; MODISE, S. J. Dynamic studies and pseudo-second order modeling of copper (II) biosorption onto pine cone powder. Desalination, 251: 112-122, 2010.

PAUL, A. Modeling of Phosphorus Removal in a Subsurface Wetland System: Emerging Trends in Engineering and Technology 2013. 4th International Conference on Emerging Trends in Engineering and Technology (IETET 2013). Advance in Engineering and Technology, 3: 20-25, 2013.

QAFOKU, N. et al. Variable charge soils: their mineralogy, chemistry and management. Advances in Agronomy, 84:159-215, 2004.

QIAN, T. et al. Effects of environmental conditions on the release of phosphorus from biochar. Chemosphere, 93: 2069-2075, 2013.

TEIXEIRA, P. C. et al. Manual de métodos de análise de solo. 3. ed. Brasília, DF: Embrapa Solos, 2017. 574 p.

WANG, S. et al. Adsorption of phosphorus by calcium-flour biochar: Isotherm, kinetic and transformation studies. Chemosphere, 195: 666$672,2018$.
WEI, L. et al. Regulating environmental factors of nutrients release from wheat straw biochar for sustainable agriculture. Clean: Soil, Air, Water, 41: 697-701, 2013.

YAO, Y. et al. Biochar derived from anaerobically digested sugar beet tailings: Characterization and phosphate removal potential. Bioresource Technology, 102: 6273-6278, 2011.

ZHAI, L. et al. Short-term effects of maize residue biochar on phosphorus availability in two soils with different phosphorus sorption capacities. Biology and Fertility of Soils, 51: 113-122, 2015.

ZHANG, H. et al. Roles of biochar in improving phosphorus availability in soils: a phosphate adsorbent and a source of available phosphorus. Geoderma, 276: 1-6, 2016.

ZHANG, L. et al. Kinetic and isotherms studies of phosphorus adsorption onto natural riparian wetland sediment: linear and non-linear methods. Environmental Monitoring and Assessment, 187: 371-381, 2015 